\section{(1) \\ GEORGE Fox \\ UNIVERSITY}

\section{Digital Commons@ George Fox University}

Faculty Publications School of Business

1988

\title{
Consumer Valuation of Protection from Creditor Remedies
}

Gregory A. Falls

Central Michigan University

Debra Worden

George Fox University, dworden@georgefox.edu

Follow this and additional works at: http://digitalcommons.georgefox.edu/gfsb

Part of the Business Commons

\section{Recommended Citation}

Falls, Gregory A. and Worden, Debra, "Consumer Valuation of Protection from Creditor Remedies" (1988). Faculty Publications School of Business. Paper 36.

http://digitalcommons.georgefox.edu/gfsb/36 


\section{Consumer Valuation of Protection from Creditor Remedies}

This study investigates the values consumers place on restrictions of creditor remedies. The unique data employed were derived from a 1979 consumer survey taken across four local credit markets that difiered significantly in their legal environments. The results of binomial logit analysis identified the characteristics of consumers who were willing to pay for contractual protection from several creditor remedies. A study of the dollar amounts that consumers were inclined to pay provided few significant results.

One aspect of the legal environment for consumer credit is the restrictions placed on remedies that creditors may use to collect delinquent and defaulted debts. A major change in this legal setting occurred on March 1, 1985 when, after ten years of rule making, the Federal Trade Commission (FTC) published its Credit Practice Rule. The regulation prohibits consumer credit contracts from including confessions of judgment, waivers that exempt certain property from creditor's claims, the assignment of future wages, the nonpurchase money security interests in household goods. It also bans the pyramiding of late charges. This ruling affects finance companies, retailers, and federal credit unions. The Federal Reserve Board and the Federal Home Loan Bank Board adopted similar provisions for other financial institutions, effective January $1,1986 .{ }^{1}$ While a number of studies have examined the importance of remedies to creditors (see, for example, Dunkelberg 1978; Greer 1973; Peterson 1977; and Peterson and Frew 1977), very little research has focused on the con-

Gregory A. Falls is an Assistant Professor of Economics, Central Michigan University, and Debra Drecnik Worden is a Senior Research Scholar, Credit Research Center, Purdue University.

'Both the Federal Reserve Board and the Federal Home Loan Bank Board were required to adopt similar Credit Practice Rules, unless they could assert that the relevant practices were not unfair or deceptive as engaged in by banks and saving institutions, respectively. Various issues of the Washington Credit Letter (1984 and 1985) discuss these rulings and compare the three versions. 
sumers' view of these procedures, even though it is the consumer whose "rights" are supposedly protected by the remedy restrictions."

Analysis begun by Peterson and Falls (1981) and continued by Peterson (1986) attempted to show that creditors do consider consumers' attitudes about collection procedures. Both studies posited that a "goodwill" effect in the marketplace discourages creditors from using remedies that are unpopular with current or potential clientele. Only if the return provided by the remedy in the collection process is greater than the "goodwill" loss will the creditor invoke a remedy greatly disliked by consumers. Thus, it was concluded that it is not necessary for the majority of consumers to eliminate all remedies from credit contracts through legislative action or to bargain directly with creditors to eliminate specific remedies.

While these two works examined the behavior of creditors given consumer attitudes regarding remedies, this analysis more closely examines consumer valuation of protection from this type of creditor action. In particular, we compare those consumers who derive positive values from protection with those who derive none. Consumers in this latter group may be injured by mandated restrictions on remedies, because creditors adjust prices and other credit terms when freedom to invoke remedies is removed. A recent study by Barth, Cordes, and Yezer (1986) concluded that such restrictions are unlikely to provide net benefits (defined as the change in consumer welfare from the increase in the demand for credit net of the decrease in supply) to the typical borrower. Although the approach used here is quite different from that of Barth, Cordes, and Yezer, a limited comparison is made later.

The next section introduces the framework for modeling consumer valuation of protection from creditor remedies. In the third section measures of the factors discussed are introduced, and the model is empirically tested. The last section contains concluding remarks.

\footnotetext{
${ }^{2}$ Disagreeing with a portion of the Credit Practice Rule, the American Financial Services Association filed suit against the FTC. The court, finding for the FTC, concluded that the use of the disputed remedies would "result in or create a significant risk of substantial economic and monetary harm to consumers as well as potential deprivations of their legal rights." Washington Credit Letter, August 5, 1985.
} 
Shay (1979) discussed negotiation between creditors and debtors in consumer credit contracts. Typically, negotiation is focused on contractual terms such as finance rates, loan maturity, and sales of credit insurance, but not on the actions the creditor can take to recover all or part of the debt in the event of default. In fact, a credit contract usually refers to only some of these remedies and, in the event of default, a whole range of legal action not specified in the contract is available to creditors-under conditions specified by law. Bargaining does not typically occur for such noncontractual items, nor is it even customary to bargain over provisions of standardized contracts. The existence of transactions and information costs leads to the development of such contracts and dissuades individual negotiation.

But the heterogeneity of consumers implies that there also are costs to standardized contracts. Since the preferences and default risks of consumers differ, benefits from individualized contracts can be derived by both creditors and debtors. For example, a borrower who recognizes higher default risk because of uncertain future income may prefer a contract with a lower interest rate (and smaller payments) and a security lien on household goods. Another individual may receive the benefits of a continuing relationship with the creditor that extends from deposit accounts and investments to loans. In these instances and others a standardized contract may not be optimal, and negotiating contract terms could yield positive net benefits to the parties involved, in spite of transactions and information costs.

Government regulation of credit terms is also a form of contract standardization. In examining the regulatory reform of creditor remedies, Shay (1979) defined the invoking of remedies as a property right for creditors and protection from them as the debtors' right. Referring to Demsetz's (1966) analysis of government intervention in the reassignment of property rights, Shay accepted the proposition that there are instances when such intervention is desirable. For example, if the cost of defining and exchanging rights inhibits negotiation. It is recognized that regulatory restrictions on credit terms or remedies affect the allocation of a scarce resource-credit. This occurs through changes in the prices and terms under which credit is granted and to whom it is granted. Thus, before deciding that intervention is called for, those consumers who value such 
restrictions should be identified and, if possible, the amount of that value determined.

Johnson (1978) analyzed the cost and benefits of creditor remedies for both creditors and consumers. He suggested that the amount a consumer would be willing to pay for protection from a particular remedy is a good measure of the value derived from restrictions imposed on that remedy. This analysis begins by examining the determinants of this value, using the framework developed by Johnson.

Assume that in the process of obtaining credit, consumers may choose to purchase from creditors insurance that guards them from specific remedies imposed in response to delinquency or default. For simplicity, assume the cost of such insurance takes the form of a onetime payment made at the beginning of the loan and also that there are no transactions or information costs to defining, exchanging, and enforcing the agreement. In return for the premium, the creditor agrees not to exercise the particular remedy to which the insurance applies. The size of the premium that a consumer would be willing to pay would depend on the benefit derived from the insurance. This benefit (B) is the expected present value of the loss that would be incurred if the creditor exercised the remedy but is avoided due to the insurance protection. For expository purposes it may be written as:

$$
B=(\operatorname{PrD})(L)(D I S),
$$

where $\operatorname{PrD}$ is the debtor's subjective probability of delinquency or default, $L$ is the value of the loss incurred when the remedy is exercised, and DIS is a factor needed to discount the future loss to the present. $^{3}$

Presumably, an individual who believed there was a zero probability of ever defaulting on a credit contract would receive no benefit from remedy insurance. A greater benefit would be perceived from insurance the more the consumer believed in the likelihood of having trouble repaying the debt. In other words, an increase in the debtor's subjective probability of delinquency or default, $\operatorname{PrD}$, directly increases the expected present value of the loss incurred without insurance and thus increases the amount the debtor is willing to pay for protection.

\footnotetext{
${ }^{3}$ This presentation is similar to Johnson's framework. See Exhibit 1 of the Appendix for a simple numerical example.
} 
The loss due to the imposition of a creditor remedy, $\mathrm{L}$, is composed of several parts. One is the actual monetary loss which may include such items as the market value of repossessed collateral or claimed household goods, the amount of a deficiency judgment placed on the consumer, late fees, or assessed attorney's fees. An increase in any of these values, including the amount outstanding at the time of default, increases the benefit derived from the insurance coverage and, thus, increases the size of the premium the consumer would be willing to pay.

In addition to the monetary loss, if the creditor imposes remedies against a consumer, this action may hinder that consumer's ability to obtain credit in the future. To some lenders a deficiency judgment or repossession on a consumer's credit record indicates excessively high default risk. Thus, another component of $L$ is the damage to creditworthiness that a consumer perceives when a remedy is imposed. A portion of this perceived damage is captured by considering the consumer's attitude toward the remedy. Presumably, consumers who consider the use of a particular remedy to be so restrictive that it should be banned by law would perceive that its imposition would severely damage their credit-worthiness. This would increase the loss, $\mathrm{L}$, more than would a remedy that the consumer found generally acceptable. It is thus hypothesized that consumers are likely to pay a higher premium for contractual protection from what they consider to be an unacceptable remedy, given the perceived higher benefit from the insurance.

Further, those consumers who are in the stages of their lives when the use of credit is greater may perceive more damage from having a remedy on their credit records. Thus, it is hypothesized that they also would be willing to pay a higher premium to protect their creditworthiness than consumers who use less credit for consumption.

Finally, the likelihood that a remedy would be exercised, and therefore appear on a credit history, is influenced by the legal environment of the consumer's home state. In those states where lenders are restricted from exercising a particular remedy, it is expected that an informed consumer would be less willing to pay for protection from its use. A second legal aspect is the existence of a binding usury ceiling. Peterson (1986) and others have shown that lenders operating in this restricted rate environment are more likely to make use of permitted remedies quickly. Thus, it is hypothesized that an informed consumer would be more willing to pay for protection from creditor 
remedies in those states with relatively low loan rate ceilings. Also, since lenders faced with binding rate ceilings typically require higher minimum loan amounts, the component of $\mathrm{L}$ that includes the amount of the defaulted loan could be higher in those states. Thus, consumers may be willing to pay more for protection.

The discount factor, DIS, is related to the relative value a consumer places on current versus future consumption. The more highly a consumer values current consumption, the larger the opportunity cost of foregoing it until later and the smaller the discount factor needed to bring future monetary values to the present. Thus, the present value of a future loss is smaller to the individual who values current consumption more highly. As this loss, calculated in equation (1), decreases, it commands a lower insurance premium.

To reiterate, it is proposed that the up-front premium which an individual will pay for protection against the imposition of a creditor remedy is the expected present value of the loss that is avoided by purchase of the insurance. This value is positively related to the potential loss to the debtor, the subjective probability of delinquency or default, the existence of a binding rate ceiling in the local credit market, and the discount factor. It is negatively related to both the consumer's belief that the remedy is acceptable and the degree to which a remedy is restricted or prohibited.

\section{EMPIRICAL ANALYSES}

The data used in the analysis are unique-taken from households surveyed in four local credit markets that differed significantly in their legal environments. ${ }^{4}$ The 3,572 households were interviewed in early 1979 and resided in Little Rock/North Little Rock, Arkansas; Racine/Kenosha, Wisconsin; Waukegan/North Chicago, Illinois; and Lake Charles, Louisiana. These areas had similar demographic and economic characteristics. But at the time of the survey, the Arkansas and Wisconsin markets had generally lower consumer loan rate ceilings than the other two. Further, the use of creditor remedies was more restricted in Wisconsin and Louisiana than in Arkansas and Illinois. ${ }^{5}$

'The data are derived from the 1979 National Science Foundation Consumer Survey, conducted by the Credit Research Center, Purdue University.

${ }^{3}$ The levels of the rate ceilings in 1979 can be obtained from the authors on request. See Exhibit 2 of the Appendix for a description of the remedy restrictions across the four markets. 
TABLE 1

Mean Dollar Amount Consumers Are Willing to Pay for Protection from Creditor Remedies

\begin{tabular}{lcccc}
\hline & Late Fees & Repossession & $\begin{array}{c}\text { Attorney's } \\
\text { Fees }\end{array}$ & $\begin{array}{r}\text { Deficiency } \\
\text { Judgement }\end{array}$ \\
\hline Overall & $\$ 47$ & $\$ 132$ & $\$ 112$ & $\$ 93$ \\
Life Cycle Stage & & & & \\
$<45$ and married & 40 & 102 & 105 & 83 \\
$<45$ and single & 55 & 160 & 116 & 112 \\
Single parent & 42 & 160 & 116 & 108 \\
Married parent & 42 & 102 & 113 & 84 \\
$>45$, working & 41 & 119 & 107 & 84 \\
$>45$, not in labor force & 71 & 175 & 140 & 109 \\
Credit Market & & & & \\
$\quad$ Wisconsin & 39 & 84 & 110 & 75 \\
Illinois & 39 & 109 & 105 & 79 \\
Arkansas & 47 & 148 & 117 & 96 \\
$\quad$ Louisiana & 88 & 292 & 136 & 198 \\
Expect trouble repaying debts & 52 & 183 & 141 & 114 \\
No trouble repaying debts & 40 & 111 & 103 & 84 \\
\hline
\end{tabular}

In a section of the survey devoted to attitudes about credit, consumers were asked their opinions of ten creditor remedies (see Exhibit 3 of the Appendix). They were then presented with a hypothetical loan situation and asked what amount, in the form of a onetime up-front charge, they would be willing to pay for a written agreement granting protection from each of four of the remedies (see Exhibit 3 of the Appendix for details). It was implicitly assumed that no transactions or information costs were involved in the agreement. The four remedies were repossession, the assessment of late charges, the assessment of creditor's attorney's fees, and the award of deficiency judgments. ${ }^{6}$

The average dollar amounts consumers were willing to pay for protection from each remedy, both overall and for various subgroups, are reported in Table 1 . About one-third of the respondents who were willing to pay a premium were unable to state an amount.

'Consumers' rankings of the listed remedies in order of general acceptance were such that the charging of late fees ranked first, repossession second, the assessment of the attorney's fees sixth, and deficiency judgments eighth out of ten possibilities. Of these four remedies, all but deficiency judgments were ranked in the top four preferred by creditors. See Tables 2 and 3 in Peterson (1986) for these rankings. 
Examination of the mean amounts indicates that Louisiana residents and those expecting to have trouble repaying their debts place a higher value on protection from each remedy than do citizens of other states and those not expecting trouble, respectively. The overall mean amount respondents were willing to pay for late fees, $\$ 47$, suggests that consumers are willing to agree to a .694 percentage point increase in the annual percentage rate of interest (APR) on the hypothetical loan to obtain a contract that limits these fees to $\$ 1$ instead of $\$ 5$ per late payment.' Barth, Cordes, and Yezer (1986) found that consumers were willing to pay an additional .045 points APR per one dollar decrease in the maximum late charge allowed per month. Thus, our results support their findings for this remedy. Similarly, the overall averages for attorney's fees and deficiency judgments result in an increase of 1.704 and 1.408 points APR, respectively. These results are also consistent with the findings of Barth, Cordes, and Yezer (1986). However, regression analysis of the reported premiums generally yielded statistically insignificant results. ${ }^{8}$ Therefore, it appears that at this point the hypotheses summarized at the end of the previous section are not supported.

The fact that approximately one-third of the respondents who stated a willingness to pay were unable to give an amount indicates the presence of an unspecifiable threshold level below which there is no definitive answer regarding the premium. Such a situation suggests the need for a qualitative response model. ${ }^{9}$ In addition, the lack of any clear pattern in the mean amounts and the paucity of readily available market data on the value of protection must cause one to wonder whether consumers have enough information to estimate the

\footnotetext{
'This figure is determined by subtracting the APR of the hypothetical loan without protection from the corresponding figure when the insurance is purchased. The 48 month $\$ 4,000$ loan without contractual protection from the $\$ 5$ late fee has an APR of approximately 12.015. The APR with insurance is determined by assuming the same loan and payment situation but with, in the case of late fees, a $\$ 47$ up-front charge. This gives an APR of 12.709. Thus, the difference of .694 is reported. This difference obviously depends upon a number of factors (e.g., the term of the loan) and is offered only as a rough comparison with Barth, Cordes, and Yezer (1986). A similar procedure is followed for attorney's fees and deficiency judgments. Barth, Cordes, and Yezer did not consider repossession of the purchased good, althugh bans on real estate and general security interests were included.

'These results are not reported here but are available from the authors on request.

'By adopting the appropriate normalization for the parameters of such a model, the unknown threshold can be set equal to zero (see Amemiya 1981). The authors would like to thank an anonymous referee for pointing this out.
} 
cost to them of the imposition of a remedy reasonably. ${ }^{10}$ While consumers may be unable to give an amount, this does not preclude the possibility that they can indicate whether protection has any positive value to them. Thus, for the above reasons the primary analysis focuses on the qualitative question of whether consumers are willing to pay for contractual protection at all, not on the amount of the payment.

To analyze the discrete choice problem of whether consumers are willing to pay for contractual protection from creditor remedies, a binary logit model was selected. This model determines the probability that an individual with a given set of attributes will make one choice rather than the alternative. The binary dependent variable took the value of one if the consumer placed a positive value on protection from the particular remedy and zero otherwise. ${ }^{11}$ The questions which asked the respondents to ascertain this value and the hypothetical loan situation to which it applied are shown in Exhibit 3 of the Appendix. The explanatory variables are measures of those factors which compose equation (1).

The debtor's subjective probability of delinquency or default, PrD, was measured by whether the respondent expected to have trouble repaying debt commitments in the following year or two. To quantify this expectation a binary variable, DEF, was created. This variable took the value of one if the consumer admitted that chances of repayment problems were "very" or "somewhat" likely and zero if the chances were "not very" or "not at all" likely. ${ }^{12}$ The question utilized in constructing DEF is contained in Exhibit 3 of the Appendix. As implied in the theoretical discussion above, the coefficient associated with DEF is expected to be positive.

The hypothetical loan situation in the survey artificially fixed the actual monetary loss incurred by the consumer if the remedy was imposed. Because, for any particular remedy, this value did not vary across the sample, it was not included in the analysis. Other com-

\footnotetext{
${ }^{10}$ The first phenomenon may also be attributed to the brevity of the questions asked, the hypothetical nature of the situation presented, and the fact that the questions were asked near the end of the lengthy survey.

"In other words, the dependent variable took the value of one for those consumers who stated an amount and for those who could not state the exact amount they would pay as a premium, but did say they would pay something.

${ }^{12} \mathrm{~A}$ continuous variable measuring this subjective probability is desirable, but is not available from the data base.
} 
ponents of the loss, $\mathrm{L}$, were estimated. To capture a portion of the perceived damage to credit-worthiness when a remedy is imposed, this study includes a measure of the consumer's attitude about the acceptability of a remedy. Respondents were asked whether lenders should be permitted to use a particular remedy in the case of delinquency or default. If an individual believed the creditor should not be permitted to use the remedy, the variable ATT was assigned the value one, zero otherwise. (The question needed to construct this predictor is presented in Exhibit 3 of the Appendix.) The coefficient of this variable is also expected to be positive.

Another portion of the perceived damage to credit-worthiness was captured by a measure of the life-cycle stage of the debtor household. This was accomplished by creating four binary variables. For those households in their family formation years, consisting of young (less than 45 years of age) married couples, FAMILY took a value of one, zero otherwise. YGSNG and SNGPAR were similarly constructed for young single people with no children in the home and for single parents of any age, respectively. The variable OLDWRK took the value one for those households headed by older people still in the labor force. Households headed by older people who were either retired or otherwise not in the labor force were left in the constant. It is expected that this last group of older households, with lower demand for credit, should be less concerned about their abilities to obtain credit in the future. Thus, insurance protection from the damaging of their credit-worthiness is less valuable and commands little or no premium. This suggests that the coefficients of each of the included variables should be positive.

The legal setting of the consumer's local credit market was also accounted for in the analysis. The variable $R R$ took a value of one for the two markets where the creditor remedy was restricted or prohibited, zero otherwise. Given the binding rate ceilings on consumer credit in Wisconsin and Arkansas at the time of the survey, the variable LRC took a value of one for these two markets, zero otherwise. In light of earlier theoretical discussion, the coefficient of RR is expected to be negative and that of LRC positive.

Capital market theory is used to derive a proxy for the discount factor of equation (1). Capital markets and the ability to borrow and lend resources free an individual's consumption pattern from the constraint of present income earnings. In particular, the ability to use credit allows individuals today to consume more than is allowed by 
current income alone. It is hypothesized that the value of current versus future consumption is higher and, thus, the discount factor is smaller for consumers who have larger amounts of debt relative to income. The ratio of outstanding consumer installment debt to household income, denoted DEBTRAT, was created to measure this consumer preference. This debt measure included revolving credit card debt but excluded credit card obligations paid in full each month, as well as other lines of credit, rent, and mortgage payments. Because an increase in DEBTRAT implies a decrease in the discount factor, the coefficient of this variable is expected to be negative.

A summary of the independent variables is provided below:

\begin{tabular}{|c|c|}
\hline DEF & $\begin{array}{l}=1 \text { respondent "very" or "somewhat" likely to have trouble } \\
\text { repaying debt, 0 if "not very" or "not at all" likely, }\end{array}$ \\
\hline ATT & dy, 0 otherwise, \\
\hline & $<<45$ and married, 0 otherwise, \\
\hline & $=$ \\
\hline & at is single pa \\
\hline & in labor force, 0 otherwise, \\
\hline & 1 remedy is restricied or prohibited in market, 0 other \\
\hline & rkets, 0 othe \\
\hline & ment debt/household incom \\
\hline
\end{tabular}

The results of the logit estimation are presented in Table $2 .{ }^{13}$ The overall fit of the model can be evaluated by the likelihood ratio statistic, $-2 \log \lambda$. This statistic is distributed as a chi square $(r)$, where $r$ equals the number of explanatory variables. Similar to the F test in ordinary regression analysis, this statistic tests the null hypothesis that all coefficients are zero. As reported in Table 2, this hypothesis is rejected at the 95 percent level of confidence. Further, for each of the four equations, the full logit model correctly predicts about twothirds of the consumers' choices.

The asymptotic properties of the maximum likelihood parameter estimates allow the use of t-tests for the coefficients of explanatory variables. Given the binary nature of each variable, a positive (negative) significant coefficient indicates that the likelihood that a consumer would pay for protection from the remedy is greater (less) when the variable takes the value of one than when it takes the value of zero.

"See McFadden (1974) for a derivation of this model and the test statistics associated with it. 
TABLE 2

Determinants of Consumers' Willingness to Pay for

Contractual Protection from Creditor Remedies

\begin{tabular}{|c|c|c|c|c|}
\hline \multirow[b]{2}{*}{$\begin{array}{l}\text { Independent } \\
\text { Variables }\end{array}$} & \multicolumn{4}{|c|}{ Dependent Variables } \\
\hline & Late Fees & Repossession & $\begin{array}{l}\text { Attorney's } \\
\text { Fees }\end{array}$ & $\begin{array}{r}\text { Deficiency } \\
\text { Judgment }\end{array}$ \\
\hline DEF & $\begin{array}{r}0.16^{*} \\
(4.63)\end{array}$ & $\begin{array}{r}0.68^{*} \\
(5.07)\end{array}$ & $\begin{array}{c}0.47^{*} \\
(3.07)\end{array}$ & $\begin{array}{r}0.74^{*} \\
(5.41)\end{array}$ \\
\hline ATT & $\begin{array}{l}0.27^{*} \\
(2.51)\end{array}$ & $\begin{array}{l}0.30^{*} \\
(2.89)\end{array}$ & $\begin{array}{c}0.06 \\
(0.57)\end{array}$ & $\begin{array}{l}0.28^{*} \\
(2.74)\end{array}$ \\
\hline \multicolumn{5}{|l|}{ Life Cycle } \\
\hline FAMILY & $\begin{array}{c}0.06 \\
(0.44)\end{array}$ & $\begin{array}{c}0.08 \\
(0.58)\end{array}$ & $\begin{array}{c}0.30^{*} \\
(1.66)\end{array}$ & $\begin{array}{l}-0.09 \\
(0.60)\end{array}$ \\
\hline YGSNG & $\begin{array}{c}0.55^{*} \\
(3.11)\end{array}$ & $\begin{array}{c}0.42^{*} \\
(2.35)\end{array}$ & $\begin{array}{c}0.95^{*} \\
(4.53)\end{array}$ & $\begin{array}{c}0.34^{*} \\
(1.83)\end{array}$ \\
\hline SNGPAR & $\begin{array}{c}0.28 \\
(1.53)\end{array}$ & $\begin{array}{c}0.29 \\
(1.54)\end{array}$ & $\begin{array}{r}0.44^{*} \\
(1.94)\end{array}$ & $\begin{array}{c}0.12 \\
(0.64)\end{array}$ \\
\hline OLDWRK & $\begin{array}{l}-0.01 \\
(0.04)\end{array}$ & $\begin{array}{l}-0.11 \\
(0.73)\end{array}$ & $\begin{array}{c}0.24 \\
(1.25)\end{array}$ & $\begin{array}{l}-0.17 \\
(1.08)\end{array}$ \\
\hline RR & $\begin{array}{l}-0.23^{*} \\
(2.49)\end{array}$ & $\begin{array}{l}-0.24^{*} \\
(2.55)\end{array}$ & $\begin{array}{l}-0.29^{*} \\
(2.64)\end{array}$ & $\begin{array}{l}-0.27^{*} \\
(2.70)\end{array}$ \\
\hline LRC & $\begin{array}{c}0.12 \\
(1.35)\end{array}$ & $\begin{array}{l}0.19^{*} \\
(1.98)\end{array}$ & $\begin{array}{l}0.19^{\star} \\
(1.76)\end{array}$ & $\begin{array}{c}0.16 \\
(1.51)\end{array}$ \\
\hline DEBTRAT & $\begin{array}{c}-0.00 \\
(0.45)\end{array}$ & $\begin{array}{c}-0.00 \\
(0.50)\end{array}$ & $\begin{array}{l}-0.00 \\
(0.05)\end{array}$ & $\begin{array}{l}-0.00 \\
(0.86)\end{array}$ \\
\hline Constant & $\begin{array}{l}1.22^{*} \\
(8.87)\end{array}$ & $\begin{array}{l}1.22^{*} \\
(8.79)\end{array}$ & $\begin{array}{c}1.66^{*} \\
(9.49)\end{array}$ & $\begin{array}{l}1.30^{*} \\
(8.59)\end{array}$ \\
\hline $\mathrm{n}$ & 2576 & 2535 & 2211 & 2457 \\
\hline$-2 \log \lambda$ & $61.5^{*}$ & $75.1^{*}$ & $51.7^{*}$ & $68.0^{*}$ \\
\hline $\begin{array}{r}\% \text { correctly } \\
\text { predicted }\end{array}$ & $62 \%$ & $63 \%$ & $66 \%$ & $64 \%$ \\
\hline
\end{tabular}

${ }^{a}$ The absolute value of the $t$-ratio is given in parentheses below each estimated coefficient.

*Significant at the $95 \%$ level of confidence, one-tailed test. 
For all four remedies the coefficient of DEF is significantly positive and, thus, meets a priori expectations. This indicates that consumers who anticipated having trouble meeting debt commitments were more willing to pay for protection from these remedies than those who did not expect such problems.

The attitude variable (ATT) significantly captures consumers' perceived losses from the imposition of remedies. Except for protection from attorney's fees, those consumers who believed a remedy was unacceptable were more likely to pay for protection. As expected, young single persons were more willing to contract for protection against remedies than households headed by older people not in the labor force. The coefficients on the other life-cycle variables were not statistically significant. Additional analysis of this data (not presented here) indicated that these young single consumers were significantly more likely to shop for the best deal before signing a credit contract.

Holding all other factors constant, consumers borrowing in markets where the imposition of remedies was restricted were less willing to pay for protection from the remedies. In partial accord with prior expectation, the presence of binding rate ceilings has a significantly positive effect on consumers' willingness to contract for protection from repossession and the payment of attorney's fees, but they have no effect for the other two remedies.

The variable DEBTRAT is insignificant for all remedies. This suggests that the discount factor is not an empirically important variable. Several alternatives to DEBTRAT were also utilized, with similar results.

\section{CONCLUDING REMARKS}

The purpose of this study was to evaluate the consumers' view of restrictions on remedies imposed by lenders in case of delinquency or default on a loan contract. In particular, we chose to investigate what factors influence the value consumers place on protection from these creditor actions.

Although we were unable to capture the determinants of how much consumers would be willing to pay for protection, analysis of their willingness to pay yielded significant results. This analysis implied that the consumers in our sample were aware of the factors which affect the cost they would incur when a remedy is exercised. 
For instance, consumers who acknowledged a higher risk of default were more willing to pay for protection from creditor remedies, under the realization that the remedial action was more likely to be imposed.

The sample data were drawn from credit markets that differed in the level of interest rate ceilings and restrictions of remedies. With this data we ascertained that consumers seem aware of the legal environment that influences the imposition of remedies. In sum, we found evidence that, in the absence of transactions costs, some consumers recognized a positive value of protection from creditor remedies, while others found no need for it. Further, the former were willing to pay lenders to obtain such protection.

However, as indicated by the analysis of how much they would pay for protection from creditor remedies, consumers may be unable to appraise the potential harm of such creditor action. Such imperfect borrower knowledge could be corrected through public education or through legislation which mandates that lenders provide more complete information themselves.

\section{APPENDIX}

\section{EXHIBIT I}

Assume that, on a three month loan, a consumer estimates that a $\$ 1,000$ loss, $\mathrm{L}$, is incurred if a default occurs at any time during the term of the loan. This $\$ 1,000$ includes both the monetary loss and any damage to the debtor's credit-worthiness. The consumer believes that there is only a ten percent probability that the loan will be defaulted at some time during the term of the contract. In the event of default, there is a 50 percent chance that it will happen during the first month, a 30 percent chance and a 20 percent chance it will happen during the second and third months, respectively.

Given a twelve percent annual discount rate-that is, the consumer is indifferent between $\$ 100$ today and $\$ 112.68$ in one year (assuming monthly compounding)-the expected present value of the loss from default is

$$
.10[.50(.990 \times \$ 1000)+.30(.980 \times \$ 1000)+.20(.971 \times \$ 1000)]=\$ 98.32
$$

The consumer would benefit by $\$ 98.32$ if this loss could be avoided. 
EXHIBIT 2

Creditor Remedy Restrictions in Survey States in 1979

\begin{tabular}{|c|c|c|c|c|}
\hline \multirow[b]{2}{*}{ Restriction } & \multicolumn{4}{|c|}{ State } \\
\hline & Arkansas & Illinois & Louisiana & Wisconsin \\
\hline $\begin{array}{l}\text { Overall level of } \\
\text { restrictions }\end{array}$ & $\begin{array}{l}\text { Not highly } \\
\text { restrictive }\end{array}$ & $\begin{array}{l}\text { Not highly } \\
\text { restrictive }\end{array}$ & Highly restrictive & Highly restrictive \\
\hline $\begin{array}{l}\text { Late payment } \\
\text { charges }\end{array}$ & No provision & $\begin{array}{l}\text { Lesser of } \$ 10 \text { or } \\
5 \%\end{array}$ & $\begin{array}{l}\text { Lesser of max. } \\
\text { rate, } 3 \% \text { or } \$ 5\end{array}$ & $\begin{array}{l}\text { Lesser of } \$ 3 \text { or } \\
3 \%\end{array}$ \\
\hline Repossession & $\begin{array}{l}\text { Self-help allowed } \\
\text { under UCC }\end{array}$ & $\begin{array}{l}\text { Self-help allowed } \\
\text { under UCC }\end{array}$ & $\begin{array}{l}\text { "Sequestration" } \\
\text { requires replevin } \\
\text { by legal } \\
\text { authority }\end{array}$ & $\begin{array}{l}\text { Requires prior } \\
\text { judicial process }\end{array}$ \\
\hline $\begin{array}{l}\text { Assessment of } \\
\text { attorney's fees }\end{array}$ & $\begin{array}{l}\text { Limited to } 10 \% \\
\text { of principal }+ \\
\text { interest }\end{array}$ & $\begin{array}{l}\text { Reasonable fees } \\
\text { allowed }\end{array}$ & $\begin{array}{l}\text { Up to } 25 \% \text { of } \\
\text { balance due }\end{array}$ & $\begin{array}{l}\text { Prohibited in } \\
\text { consumer credit }\end{array}$ \\
\hline $\begin{array}{l}\text { Deficiency } \\
\text { judgments }\end{array}$ & $\begin{array}{l}\text { Allowed under } \\
\text { UCC }\end{array}$ & $\begin{array}{l}\text { Allowed but } \\
\text { may not be } \\
\text { available in } \\
\text { some cases }\end{array}$ & $\begin{array}{l}\text { No provision but } \\
\text { recovery of } \\
\text { deficiencies is } \\
\text { prohibitively } \\
\text { expensive }\end{array}$ & $\begin{array}{l}\text { Prohibited for } \\
\text { loans under } \\
\$ 1,000\end{array}$ \\
\hline
\end{tabular}

Source: Peterson and Falls (1981), "Costs and Benefits of Restrictions on Creditors' Remedies," Working Paper No. 41, Credit Research Center, Purdue University.

\section{EXHIBIT 3 \\ Questions on Consumers' Attitudes Towards Remedies}

Sometimes people have difficulty in paying their debts and fall behind in their payments. When this happens, creditors have several courses of action that they may follow. In your opinion, which of these should a creditor be permitted to do to collect a debt that is owed? To ascertain consumer attitudes they were then asked:

Charge an extra fee if payments are late by $\mathbf{3 0}$ days or more?

Renegotiate the loan with lower monthly payments, but at a higher interest rate?

Call the consumer at regular intervals to remind him that the debt must be paid?

Contact the consumer's employer about the debt owed?

Take back the item purchased on credit? 
Take back and sell the item purchased, then sue for any amount owed but not covered by the sale?

If no particular item was purchased with the loan, take household goods and sell them to pay off the debt?

Ask an employer to take part of the consumer's wages to pay off the debt?

Legally force the consumer to pay the creditor's legal fees if the creditor has to sue?

Legally force the consumer to use money in savings accounts to pay off the debts?

\section{Questions on Consumers' Willingness to Pay for Remedy Protection}

At times some people have difficulty repaying loans. This could happen because of unexpected layoffs, job losses, sickness, death, or family financial problems. When people fall behind on their payments, lenders may use a number of legal "remedies" to try and get their money back. We are interested in how much extra money people might be willing to pay in order to borrow money from a lender who agreed in writing that he would not use certain "remedies" in collecting money owed.

Suppose you borrowed $\$ 4,000$ for 48 months for a new car. You would have to pay back approximately $\$ 1,000$ in finance charges on the loan in addition to the $\$ 4,000$ borrowed. To ascertain how much consumers would be willing to pay for protection from the assessment of the lender's attorney's fees, they were asked:

How much extra in a one-time charge or fee would you be willing to pay to borrow from a lender who would give you a loan contract that would not make you pay his attorney's fees (which might be as much as $\$ 300$ ) if he had to sue you to collect on the loan?

To ascertain how much consumers would be willing to pay for protection from paying late charges, they were asked:

Many lenders can assess "late charges" if your payment is more than two weeks late. If a lender would agree to assess a late charge of \$1 rather than $\$ 5$ for each payment overdue, how much extra 
would you be willing to pay in a one-time charge or fee to obtain a $\$ 4,000,48-$ month loan from such a lender?

If a borrower stopped paying on an auto loan when he still owed $\$ 2,000$ and the car was worth only $\$ 1,500$, the lender can take back the car and then sue for the extra $\$ 500$. To ascertain how much consumers would be willing to pay for protection from repossession, they were asked:

How much extra would you be willing to pay in a one-time charge or fee to obtain a $\$ 4,000,48$-month new car loan from a lender who agreed that if you stopped paying, he could only sue for the balance due on the loan $(\$ 2,000)$ but could not take back the car?

To ascertain how much consumers would be willing to pay for protection from the awarding of a deficiency judgment to lenders, they were asked:

Now, suppose the lender agreed that if the borrower stopped paying, the lender would only take back the car (worth $\$ 1,500$ ) but would not sue for the difference (\$500). How much extra in a onetime charge or fee would you pay for such an agreement?

\section{Questions on Consumers' Subjective Probability of Default}

How likely do you think it is that you might have trouble repaying some of your debts in the next year or two. Would you say it is ...

Very likely

Somewhat likely

Not very likely

Not at all likely

\section{REFERENCES}

Amemiya, Takeshi (1981), "Qualitative Response Models: A Survey," Journal of Economic Literature, 19 (December): 1485-1536.

Barth, James R., Joseph J. Cordes, and Anthony M. J. Yezer (1986), "Benefits and Costs of Legal Restrictions on Personal Loan Markets," Journal of Law and Economics, 29 (October): 357-380.

Demsetz, Harold (1966), "Some Aspects of Property Rights," Journal of Law and Economics, 9 (October): 61-70. 
Dunkelberg, William C. (1978), “Banks' Lending Response to Restricted Creditor Remedies," Working Paper No. 21, West Lafayette, IN: Credit Research Center, Purdue University. Greer, Douglas F. (1973), Creditors' Remedies and Contract Provisions: An Economic and Legal Analysis of Consumer Credit Collection, National Commission on Consumer Finance, Technical Studies, Vol. V, Washington, DC: Government Printing Office.

Johnson, Robert W. (1978), Cost/Benefit Analysis of Creditors' Remedies, Monograph No. 12, West Lafayette, IN: Credit Research Center, Purdue University.

McFadden, Daniel (1974), "Conditional Logit Analysis of Qualitative Choice Behavior," in Frontiers in Econometrics, Paul Zarembka, ed., New York: Academic Press, Inc.

National Commission on Consumer Finance (1972), Consumer Credit in the United States: Report of the National Commission on Consumer Finance, Washington, DC: Government Printing Office.

Peterson, Richard L. (1977), “The Impact of Creditors' Remedies on Consumer Loan Charges," Working Paper No. 15, West Lafayette, IN: Credit Research Center, Purdue University.

(1977), "The Impact of Restricted Creditors' Remedies on Automobile Finance Companies in Wisconsin." Working Paper No. 12. West Lafayette, IN: Credit Research Center, Purdue University.

(1986), "Creditors' Use of Collection Remedies," The Journal of Financial Research, 9 (Spring): 71-85.

Peterson, Richard L., and Gregory A. Falls (1981), "Costs and Benefits of Restrictions on Creditors' Remedies," Working Paper No. 41, West Lafayette, IN: Credit Research Center, Purdue University.

Peterson, Richard L., and James R. Frew (1977), "Creditor Remedy Restrictions and Interstate Differences in Personal Loan Rates and Availability: A Supplementary Analysis," Working Paper No. 14, West Lafayette, IN: Credit Research Center, Purdue University. Shay, Robert P. (1979), "Consumer Protection in Credit Markets: An Analysis of Regulatory Reform," in Issues in Financial Regulation, F. Edward, ed., New York: McGraw Hill, Inc. Washington Credit Letter, 11 (January 14-August 5, 1985).

10 (November 26, 1984). 